\title{
Streptomyces bathyalis sp. nov., an actinobacterium isolated from the sponge in a deep sea
}

\author{
Chandra Risdian (1) - Wiebke Landwehr • Manfred Rohde • Peter Schumann (10) \\ Richard L. Hahnke (iD - Cathrin Spröer • Boyke Bunk (D) Peter Kämpfer (iD • \\ Peter J. Schupp 1 - Joachim Wink
}

Received: 8 January 2021 / Accepted: 23 January 2021 /Published online: 17 February 2021

(C) The Author(s) 2021

\begin{abstract}
A novel actinobacterium, designated ASO4wet ${ }^{\mathrm{T}}$, was isolated from the unidentified sponge (SO4) in the deep sea collected of the North Atlantic Ocean. Study of $16 \mathrm{~S}$ rRNA gene sequences indicated that strain ASO4wet ${ }^{\mathrm{T}}$ is a member of the genus Streptomyces and showed the closest similarities to Streptomyces karpasiensis $\mathrm{K} 413^{\mathrm{T}}$ (98.87 \%), Streptomyces glycovorans YIM M $10366^{\mathrm{T}}(98.38 \%)$, and Streptomyces abyssalis YIM M $10400^{\mathrm{T}}(97.53 \%)$. Strain ASO4wet ${ }^{\mathrm{T}}$ contained MK-9(H8) as the
\end{abstract}

Chandra Risdian and Wiebke Landwehr contributed equally to this work.

C. Risdian · W. Landwehr · J. Wink $(\bowtie)$

Microbial Strain Collection (MISG), Helmholtz Centre

for Infection Research (HZI), 38124 Braunschweig,

Germany

e-mail: Joachim.Wink@helmholtz-hzi.de

C. Risdian

Research Unit for Clean Technology, Indonesian Institute of Sciences (LIPI), 40135 Bandung, Indonesia

W. Landwehr

Partner Site Hannover-Braunschweig, German Centre for Infection Research (DZIF), Braunschweig, Germany

M. Rohde

Central Facility for Microscopy, Helmholtz Centre for Infection Research (HZI), 38124 Braunschweig, Germany predominant menaquinone and the major fatty acids are iso- $\mathrm{C}_{16: 0}$, anteiso- $\mathrm{C}_{15: 0}$, and iso- $\mathrm{C}_{15: 0}$. Polyphasic taxonomy was carried out between strain ASO4wet ${ }^{\mathrm{T}}$ and its phylogenetically closely related Streptomyces strains, which further elucidated their relatedness and revealed that strain ASO4wet ${ }^{\mathrm{T}}$ could be distinguished from currently known Streptomyces species. Strain ASO4wet ${ }^{\mathrm{T}}$ clearly represents a novel species in genus Streptomyces. We propose the name Streptomyces bathyalis sp. nov., with the type strain ASO4wet ${ }^{\mathrm{T}}$ $\left(=\operatorname{DSM} 106605^{\mathrm{T}}=\operatorname{NCCB} 100657^{\mathrm{T}}\right)$. Analysis of the whole-genome sequence of $S$. bathyalis revealed that

\footnotetext{
P. Schumann · R. L. Hahnke · C. Spröer · B. Bunk Leibniz Institut DSMZ-German Collection of Microorganisms and Cell Cultures, 38124 Braunschweig, Germany

P. Kämpfer

Institut für Angewandte Mikrobiologie, Justus-Liebig-

Universität Giessen, 35392 Giessen, Germany

P. J. Schupp

Institute for Chemistry and Biology of the Marine

Environment, Carl von Ossietzky University of

Oldenburg, 26129 Oldenburg, Germany
} 
genome size is 7,377,472 bp with 6332 coding sequences.

Keywords Deep-sea sponge - The North Atlantic Ocean · Polyphasic taxonomy $\cdot$ Streptomyces

\section{Introduction}

In the effort of finding new bioactive compounds from novel Streptomyces, some studies recently are focused on the neglected and unexplored regions in order to enlarge the successful isolation of new species (Goodfellow et al. 2017). The deep sea is one of the underexplored areas on Earth. One of the reasons is probably because of its extreme environments such as high pressure, low temperature, less oxygen concentration, and lack of light intensity. More than 30,000 marine natural products have been isolated and about $2 \%$ of those are from deep-sea organisms, including Actinobacteria from the genus Streptomyces, Marinactinospora, and Verrucosispora (Tortorella et al. 2018).

Previously, some strains and species such as Streptomyces sp. NTK 937 (Hohmann et al. 2009), Streptomyces olivaceus FXJ8.012 (Liu et al. 2013), Streptomyces sp. SCSIO 04496 (Luo et al. 2015), Streptomyces indicus (Luo et al. 2011), and Streptomyces nanhaiensis (Tian et al. 2012) were reported to be isolated from the deep-sea sources. Streptomyces nanhaiensis was found in the northern South China Sea at $1632 \mathrm{~m}$ below sea level (Tian et al. 2012), while Streptomyces indicus was isolated from the Indian Ocean depth of $2434 \mathrm{~m}$ (Luo et al. 2011).

Streptomyces is a genus of aerobic Gram-positive bacteria and one of its characters is the morphology that contains substrate and aerial mycelia (Williams et al. 1983). A minor amount of species of this genus was reported having no aerial mycelia such as Streptomyces somaliensis (Brumpt 1906) Waksman and Henrici 1948 (Approved Lists 1980) (Skerman et al. 1980) and Streptomyces sudanensis (Quintana et al. 2008). Streptomyces is one of the genera from Actinobacteria and many of them are isolated from soil (Ritacco et al. 2003; Risdian et al. 2018); however, in some previous studies, they are also reported to be found in the rhizosphere of the plant (Xiao et al. 2009), mangrove sediment (Handayani et al. 2018), and marine sediment (Xu et al. 2012). Streptomyces is one of the important producers of antibiotics, considering that more than half of the antibiotics used nowadays are produced by this group of bacteria (Lucas et al. 2013). However, they are mainly terrestrial strains (Kemung et al. 2018).

In the course of our investigation of Actinobacteria from the deep sea in the extended Continental shelf of Portugal, near Madeira Islands, strain ASO4wet ${ }^{\mathrm{T}}$ was isolated from an unidentified sponge (SO4) collected by ROV (remotely operated vehicle) from the North Atlantic Ocean $\left(36^{\circ} 15.19038 \mathrm{~N}, 14^{\circ} 32.99767 \mathrm{~W}\right)$ at $1092 \mathrm{~m}$ water depth.

\section{Materials and methods}

Actinobacteria isolation and morphological study

The isolation of actinobacteria was performed using 5336-ASW medium (soluble starch $10.0 \mathrm{~g}$, casein $1.0 \mathrm{~g}, \mathrm{~K}_{2} \mathrm{HPO}_{4} 0.5 \mathrm{~g}, \mathrm{MgSO}_{4} .7 \mathrm{H}_{2} \mathrm{O} 5.0 \mathrm{~g}$, artificial seawater (ASW) $1000 \mathrm{ml}$, agar $20.0 \mathrm{~g}, \mathrm{pH} 7.3$ ) and incubated at $30{ }^{\circ} \mathrm{C}$. Artificial seawater (ASW) contained $3.9 \%(\mathrm{w} / \mathrm{v})$ of sea salt from ATI Coral Ocean. Morphological observations of spores and mycelia on International Streptomyces Project 2 or ISP2 agar (yeast extract-malt extract), ISP3 agar (oatmeal), ISP4 agar (inorganic salt- starch) agar, ISP5 agar (glycerolasparagine), ISP6 agar (peptone-yeast extract-iron), and ISP7 agar (tyrosine) (Shirling and Gottlieb 1966) at $30{ }^{\circ} \mathrm{C}$ for 14 days. The colours of mycelium (aerial and substrate) and diffusible pigments were evaluated by comparison with the RAL-code (https://www.ralfarben.de) (Charousová et al. 2015). Spore chain morphology and spore-surface ornamentation of strain ASO4wet ${ }^{\mathrm{T}}$ were observed after growing on ISP 3 agar medium (Shirling and Gottlieb 1966) for 4 weeks at 30 ${ }^{\circ} \mathrm{C}$ by Zeiss Merlin field emission scanning electron microscope (SEM) (Landwehr et al. 2018).

\section{Physiological and biochemical studies}

Growth of strain ASO4wet ${ }^{\mathrm{T}}$ at different temperatures $\left(15,20,25,30,37\right.$ and $\left.44{ }^{\circ} \mathrm{C}\right)$ on GYM medium (glucose-yeast extract-malt extract) and $\mathrm{pH}$ range $(\mathrm{pH}$ $2,3,4,5,6,7,8,9$ and 10) on ISP2 medium were evaluated after incubation for 14 days. Utilisation of 
carbohydrate was examined on ISP9 medium supplemented with $1 \%$ carbon sources (Shirling and Gottlieb 1966), the sodium chloride tolerance was investigated as described by Kutzner (1981), and the enzymatic activity profile analysis was conducted by using API ZYM strips (Humble et al. 1977). Antibiotic susceptibility was investigated by the disc-diffusion plate method (Bauer et al. 1966) using antibiotic discs on ISP2 agar medium incubated for 7 days at $30{ }^{\circ} \mathrm{C}$. Eight antibiotic discs were used: ampicillin $(10 \mu \mathrm{g} /$ disc), erythromycin (15 $\mu \mathrm{g} /$ disc), gentamycin $30(\mu \mathrm{g} /$ disc), tetracycline (30 $\mu \mathrm{g} / \mathrm{disc})$, vancomycin $(30 \mu \mathrm{g} /$ disc), cefotaxime (30 $\mu \mathrm{g} / \mathrm{disc})$, rifampicin $(5 \mu \mathrm{g} / \mathrm{disc})$, and penicillin $\mathrm{G}(6 \mu \mathrm{g} / \mathrm{disc})$.

\section{Phylogenetic analysis}

Extraction of DNA, PCR amplification, and purification of the 16S rRNA gene sequence was performed as described by Landwehr et al. (2016). PCR amplified templates were sequenced using a 96-capillary-system from Applied Biosystems (ABI), a 3730xl DNA Analyzer. Sequence data were compiled with the BioEdit program (Hall 1999) (http://www.mbio.ncsu. edu/BioEdit/bioedit.html). The almost-complete $16 \mathrm{~S}$ rRNA gene sequence $(1,417$ nucleotides) of strain ASO4wet ${ }^{\mathrm{T}}$ was obtained and submitted for BLAST analysis (Altschul et al. 1990) (https://blast.ncbi.nlm. nih.gov/Blast.cgi). The 16S rRNA gene sequence was deposited in GenBank as MT036271. The similarity and homology of the 16S rRNA gene sequence were examined for sequence homology with the database of 16S rRNA gene sequences from the National Center for Biotechnology Information (NCBI) (https://www. ncbi.nlm.nih.gov/). The 16S rRNA gene sequences of strain ASO4wet ${ }^{\mathrm{T}}$ and some related type strains were aligned using the CLUSTAL W algorithm (Thompson et al. 1994) from the MEGA X software package (Kumar et al. 2018). Phylogenetic analyses were performed using the maximum-likelihood (Felsenstein 1981) algorithm from MEGA X (Kumar et al. 2018). The topologies of the inferred trees were examined by bootstrap analyses (Felsenstein 1985) based on 1000 replicates. The resulting phylogenetic trees were rooted using the 16S rRNA gene sequence of Actinospica robiniae $\mathrm{GE} 134769^{\mathrm{T}}(\mathrm{AJ} 865863)$.

\section{Chemotaxonomy}

Biomass for the chemical analyses was collected by cultivation in glucose-yeast-malt extract (GYM) medium in flasks on a rotary shaker (160 revolutions per minute) at $30{ }^{\circ} \mathrm{C}$ for $3-7$ days. The freeze-dried cells from biomass were used for chemical analysis. The whole-cell diaminopimelic acid isomers and sugars were evaluated based on the method of Staneck and Roberts (1974). Menaquinones were extracted as described by Minnikin et al. (1984) and were analysed by high-performance liquid chromatography (Wink et al. 2017) equipped with diode-array detection and mass spectrometry (HPLC-DAD-MS). High-resolution electron spray ionisation mass spectrometry (HRESI-MS) data were recorded on a MaXis ESI-TOFMS spectrometer (Bruker) equipped with an Agilent 1260 series RP-HPLC system using XBridge C18 column $2.1 \times 100 \mathrm{~mm}, 1.7 \mu \mathrm{m}$. Solvent A was isopropanol and solvent $\mathrm{B}$ was acetonitrile. The gradient system was $100 \% \mathrm{~B}$ for $5 \mathrm{~min}, 35 \% \mathrm{~B}$ in 5 to $15 \mathrm{~min}$, and $50 \% \mathrm{~B}$ in 16-20 min with the flow rate was $0.6 \mathrm{~mL} / \mathrm{min}$. The temperature of the column was $40{ }^{\circ} \mathrm{C}$ and the UV-detection was at $270 \mathrm{~nm}$. The molecular formula of menaquinones was calculated using the Smart Formula algorithm, including the isotopic pattern (Bruker). The polar lipids were extracted according to Minnikin et al. (1977) and identified by two-dimensional thin-layer chromatography as described previously by Collins and Shah (1984).

Fatty acids were extracted, methylated and analysed using the Sherlock Microbial Identification (MIDI) system and the ACTIN version 6 database (Sasser 1990). For matrix-assisted linear desorption/ ionisation-time-of-flight mass spectrometry (MALDITOF MS) analysis, the isolate ASO4wet ${ }^{\mathrm{T}}$ was incubated at $30{ }^{\circ} \mathrm{C}$ for $6-8$ days. The samples were prepared using ethanol/formic acid extraction, as described by Schumann and Maier (2014).

\section{DNA-DNA hybridisation and ribotyping analysis}

DNA-DNA hybridisation was performed based on the method of Ziemke et al. (1998), except that for nick translation, $2 \mu \mathrm{g}$ DNA was labelled during $3 \mathrm{~h}$ of incubation at $15{ }^{\circ} \mathrm{C}$. This method was carried out for the DNA of strain ASO4wet ${ }^{\mathrm{T}}$ and the strain 
Table 1 Characteristics of strain ASO4wet ${ }^{\mathrm{T}}$ on various ISP agar media after incubation for 14 days at $30{ }^{\circ} \mathrm{C}$

\begin{tabular}{lllll}
\hline Agar medium & Growth & Substrate mycelium colour & Aerial mycelium colour & Soluble pigment \\
\hline Yeast extract-malt extract (ISP2) & Good & Light ivory & None & None \\
Oatmeal (ISP3) & Good & Light ivory & Grey white & None \\
Inorganic salt- starch (ISP4) & Good & Ivory & None & None \\
Glycerol-asparagine (ISP5) & Good & Light ivory & None & None \\
Peptone-yeast extract-iron (ISP6) & Sparse & Sandy yellow & None & None \\
Tyrosine (ISP7) & Sparse & Nutbrown & Light grey & None \\
\hline
\end{tabular}

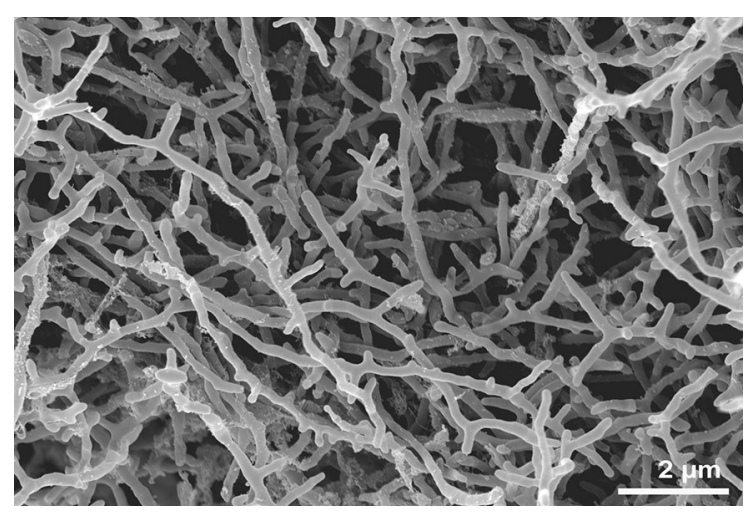

Fig. 1 Scanning electron micrographs of aerial mycelium with no spore detected of strain ASO4wet ${ }^{\mathrm{T}}$ after incubation on ISP 3 agar for 4 weeks at $30{ }^{\circ} \mathrm{C}$

Streptomyces karpasiensis DSM $42068^{\mathrm{T}}$, Streptomyces glycovorans DSM $42021^{\mathrm{T}}$, and Streptomyces abyssalis DSM $42024^{\mathrm{T}}$. Standardised and automated ribotyping analysis was conducted using the RiboPrinter system (Hygiena) involving $P v u I I$ as a restriction enzyme (Bruce 1996; Schumann and Pukall 2013).

\section{DNA extraction and complete genome sequencing}

The complete genome sequence of strain ASO4wet ${ }^{\mathrm{T}}$ was obtained via a combination of long-read PacBio and short-read Illumina-Sequencing. Therefore, DNA was isolated using Qiagen Genomic-tip 100/G (Qiagen, Hilden Germany) according to the instructions of the manufacturer. SMRTbell ${ }^{\mathrm{TM}}$ template library was prepared according to the instructions from PacificBiosciences, Menlo Park, CA, USA, following the Procedure \& Checklist - Greater Than $10 \mathrm{~kb}$ Template Preparation. Briefly, for preparation of $15 \mathrm{~kb}$ libraries $8 \mu \mathrm{g}$ genomic DNA was sheared using g-tubes ${ }^{\mathrm{TM}}$ from Covaris, Woburn, MA, USA according to the manufacturer's instructions. DNA was endrepaired and ligated overnight to hairpin adapters applying components from the DNA/Polymerase Binding Kit P6 from Pacific Biosciences, Menlo Park, CA, USA. Reactions were carried out according to the manufacturer's instructions. For the bacterial DNAs, BluePippin $^{\mathrm{TM}}$ Size-Selection to greater than $4 \mathrm{~kb}$ was performed according to the manufacturer's instructions (Sage Science, Beverly, MA, USA). Conditions for annealing of sequencing primers and binding of polymerase to purified SMRTbell ${ }^{\mathrm{TM}}$ template were assessed with the Calculator in RS Remote, PacificBiosciences, Menlo Park, CA, USA. 1 SMRT cell was sequenced on the PacBio RSII (PacificBiosciences, Menlo Park, CA, USA) taking one 240-minutes movie.

Bacterial DNAs libraries for sequencing on Illumina platform were prepared to apply Nextera XT DNA Library Preparation Kit (Illumina, San Diego, USA) with modifications according to Baym et al. (2015). Samples were sequenced on NextSeq ${ }^{\mathrm{TM}} 500$.

\section{Genome assembly and annotation}

Genome assembly performed applying the RS_HGAP_Assembly.3 protocol included in SMRT Portal version 2.3.0 using default parameters. The assembly revealed a single linear chromosome with a coverage value of $117 \mathrm{x}$. Error-correction was performed by a mapping of Illumina short reads onto finished genome using Burrows-Wheeler Alignment bwa 0.6.2 (Li and Durbin 2009) in paired-end (sample) mode using default settings with subsequent variant and consensus calling using VarScan 2.3.6 (Koboldt et al. 2012) Automated genome annotation was carried out using the NCBI Prokaryotic Genome Annotation 


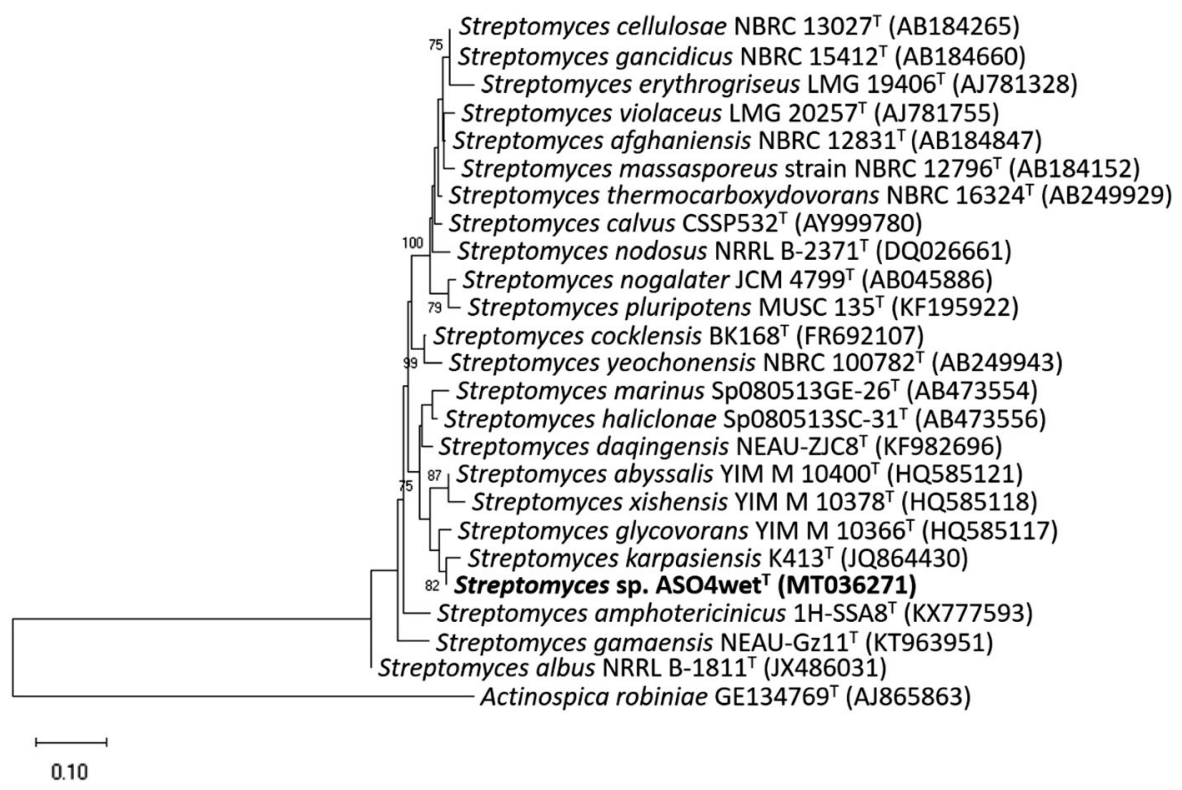

Fig. 2 Maximum-likelihood tree based on 16S rRNA gene sequences (1408 positions in the final dataset) showing relationships between strain ASO4wet ${ }^{\mathrm{T}}$ and the related type strains of Streptomyces species. The phylogenetic trees were rooted using the 16S rRNA gene sequence of Actinospica

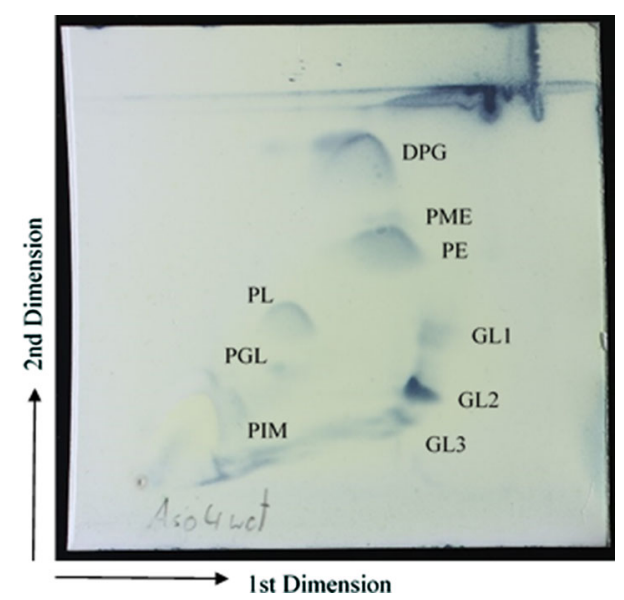

Fig. 3 Polar lipid observed in strain ASO4wet ${ }^{\mathrm{T}}$. DPG: diphosphatidylglycerol; PME: phosphatidyl-N-methyl-ethanolamine; PE: phosphatidylethanolamine; PL: unknown phospholipid; GL1-3: unknown glycolipid; PGL: unknown phosphoglycolipid; PIM: phosphatidylinositol mannoside

Pipeline PGAP (Tatusova et al. 2016). The assembly was also uploaded to RAST (Rapid Annotation using Subsystem Technology) server (https://rast.nmpdr. org/) (Aziz et al. 2008) and antiSMASH server (https://antismash.secondarymetabolites.org/) robiniae GE134769 ${ }^{\mathrm{T}}$ (AJ865863). The evolutionary distances were computed using the Tamura-Nei method (Tamura and Nei 1993). Numbers at the nodes are percentage bootstrap values with 1,000 replicates, only values above $70 \%$ are shown. Bar 0.10 substitutions per nucleotide position

(Medema et al. 2011; Blin et al. 2019) for metabolic reconstruction analysis and prediction of secondary metabolite gene clusters, respectively. The complete genome sequence of strain ASO4wet ${ }^{\mathrm{T}}$ was deposited at NCBI GenBank under accession number CP048882 in the NCBI Genome database (https://www.ncbi.nlm. nih.gov/genome).

\section{Results and discussion}

Strain ASO4wet ${ }^{\mathrm{T}}$ was found to grow well on ISP2, ISP3, ISP4, and ISP5, while sparse in ISP6 and ISP7 (Table 1). The aerial mycelium can be seen in ISP3 and ISP7. The diffusible pigment was not detected on all tested medium. The strain formed aerial mycelium, albeit no spore was detected on ISP3 agar (Fig. 1).

Strain ASO4wet ${ }^{\mathrm{T}}$ grew on medium ISP2 at $15-37^{\circ} \mathrm{C}$ (optimum at $25-30^{\circ} \mathrm{C}$ ) and at $\mathrm{pH}$ 6-9 (optimum at $\mathrm{pH}$ 7). The strain grew on CYE medium ( $10 \mathrm{~g}$ casein peptone $\mathrm{l}^{-1}, 5 \mathrm{~g}$ yeast extract $\mathrm{l}^{-1}, 20 \mathrm{~g}$ agar $\mathrm{l}^{-1}, \mathrm{pH}$ 7) supplemented with up to $10 \% \mathrm{NaCl}$. Antibiotic susceptibility test indicated that the strain was sensitive to ampicillin, erythromycin, gentamycin, 


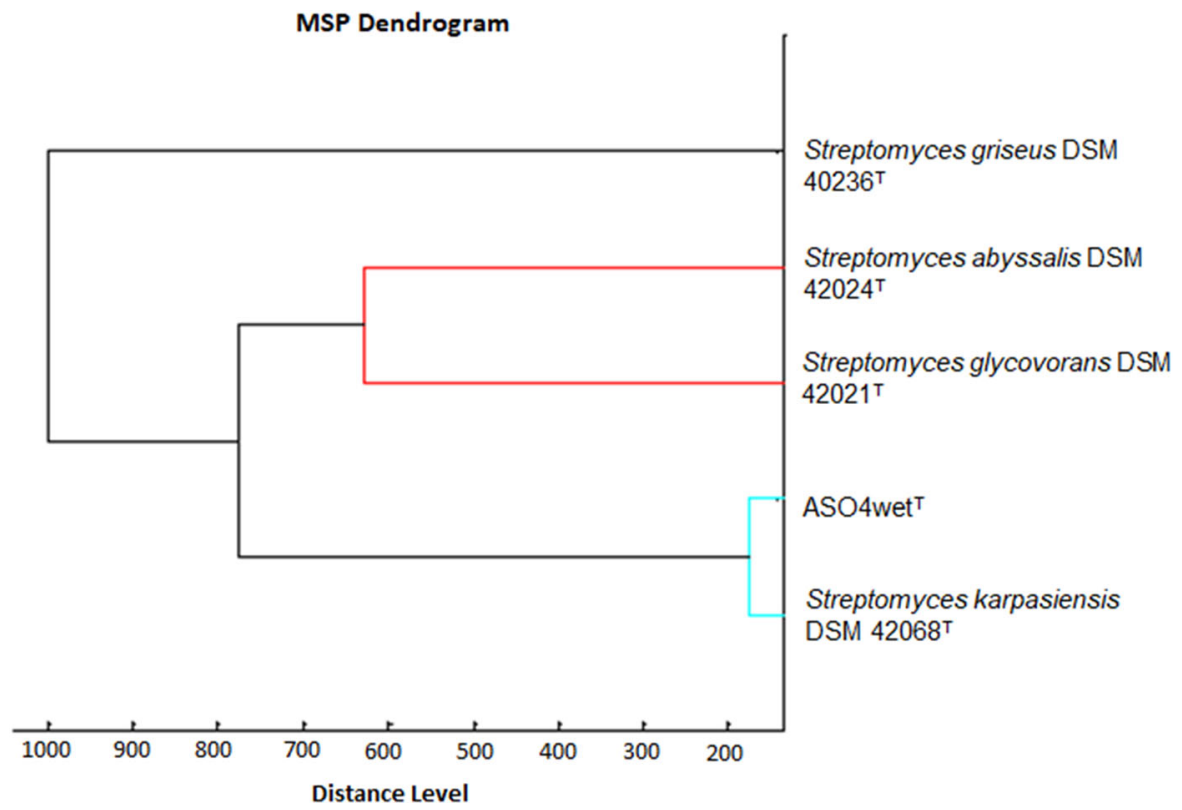

Fig. 4 MALDI-TOF dendrogram of the strain ASO4wet ${ }^{\mathrm{T}}$ and its most closely related strains. Streptomyces griseus DSM $40236^{\mathrm{T}}$ was used as an outgroup

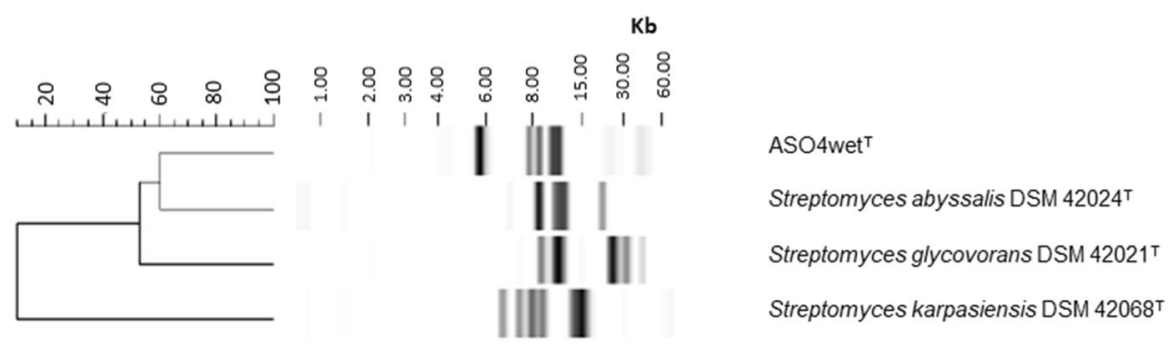

Fig. 5 Dendrogram of RiboPrinter ${ }^{\circledR}$ patterns (restriction enzyme $P v u I I$, BioNumerics Software) of the strain ASO4wet ${ }^{\mathrm{T}}$ and its closely related Streptomyces strains

penicillin $\mathrm{G}$, tetracycline, vancomycin, and rifampicin. However, it was resistant to cefotaxime $(30 \mu \mathrm{g} /$ disc).

According to the result from the NCBI server, isolate ASO4wet ${ }^{\mathrm{T}}$ related to the genus Streptomyces. The strain closely related to Streptomyces karpasiensis K413 ${ }^{\mathrm{T}}(98.87 \%)$, Streptomyces glycovorans YIM M $10366^{\mathrm{T}}(98.38 \%)$, and Streptomyces abyssalis YIM M $10400^{\mathrm{T}}(97.53 \%)$. Strain ASO4wet ${ }^{\mathrm{T}}$ formed a stable clade with Streptomyces karpasiensis $\mathrm{K} 413^{\mathrm{T}}$ that was supported by $82 \%$ bootstrap value in the maximum-likelihood tree based on the 16S rRNA gene sequence (Fig. 2).

Cell-wall hydrolysates of strains ASO4wet ${ }^{\mathrm{T}}$ contained LL-diaminopimelic acid, which is suggested that it belongs to cell-wall type I (Lechevalier and Lechevalier 1970). Whole-cell hydrolysates of strains ASO4wet ${ }^{\mathrm{T}}$ contained glucose and xylose. The major fatty acids of strain ASO4wet ${ }^{\mathrm{T}}$ were iso- $\mathrm{C}_{16: 0}$ ( 35 . $1 \%)$, anteiso- $\mathrm{C}_{15: 0}(22 \%)$, iso- $\mathrm{C}_{15: 0}(13.8 \%)$, anteiso- $\mathrm{C}_{17: 0}(8.8 \%)$, and iso- $\mathrm{C}_{14: 0}(6.3 \%)$. The menaquinone composition was identified as MK-9(H8) and MK-9(H6) in a ratio of 12:1. The polar lipids were identified as diphosphatidylglycerol, phosphatidylglycerol, phosphatidylethanolamine, phosphatidyl-Nmethyl-ethanolamine, phosphatidylinositol mannoside, and four unidentified polar lipids (Fig. 3). These chemotaxonomic properties of strain ASO4wet ${ }^{\mathrm{T}}$ had similar profiles to some species from the genus Streptomyces that have been reported 

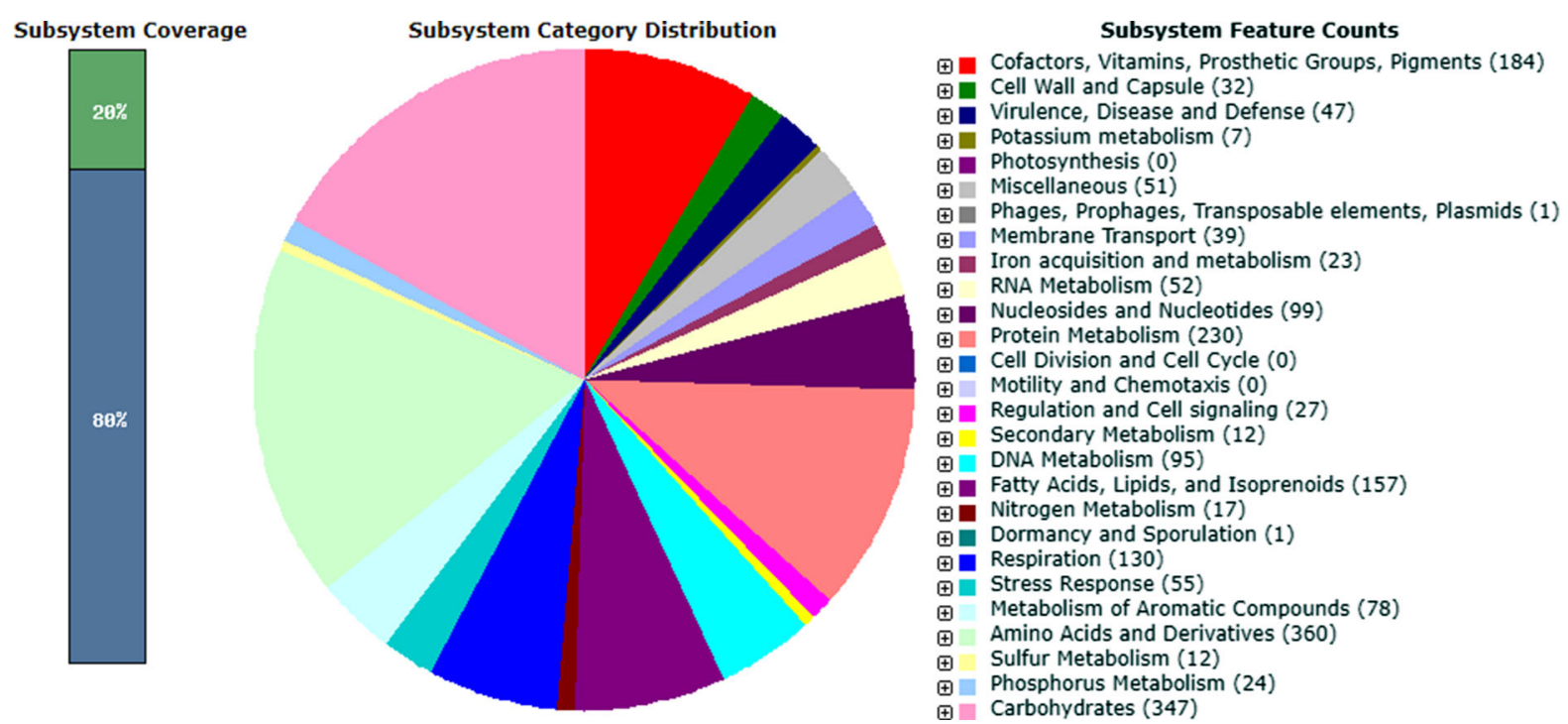

Fig. 6 Subsystem category distribution of strain ASO4wet ${ }^{T}$ based on RAST annotation server (https://rast.nmpdr.org/)

previously (Kämpfer et al. 2008; Busarakam et al. 2014; Ayed et al. 2018).

The MALDI-TOF analysis result also suggested that strain ASO4wet ${ }^{\mathrm{T}}$ formed a clade with Streptomyces karpasiensis DSM $42068^{\mathrm{T}}$ (Fig. 4). The comparison of the fingerprints using the BioNumerics software (version 7.6.1; Applied Maths, Belgium) exhibited the differences between strain ASO4wet ${ }^{\mathrm{T}}$, Streptomyces karpasiensis DSM $42068^{\mathrm{T}}$, Streptomyces glycovorans DSM $42021^{\mathrm{T}}$, and Streptomyces abyssalis DSM $42024^{\mathrm{T}}$ (Fig. 5). All strains displayed different band patterns.

To determine whether strain ASO4wet ${ }^{\mathrm{T}}$ represent a novel species, DNA-DNA hybridisation (DDH) was conducted to further delineate the relatedness between strain ASO4wet ${ }^{\mathrm{T}}$ and its closely related type strains, i.e., Streptomyces karpasiensis DSM $42068^{\mathrm{T}}$, Streptomyces glycovorans DSM $42021^{\mathrm{T}}$, and Streptomyces abyssalis DSM $42024^{\mathrm{T}}$. The levels of DNA-DNA relatedness between strain ASO4wet ${ }^{\mathrm{T}}$ and Streptomyces karpasiensis DSM $42068^{\mathrm{T}}$, Streptomyces glycovorans DSM $42021^{\mathrm{T}}$, and Streptomyces abyssalis DSM $42024^{\mathrm{T}}$ were $40.4 / 54.7 \%, 40.5 / 44.4 \%$, and $35.8 / 28.2 \%$ respectively. These values are below the threshold value of $70 \%$, as suggested by Wayne et al. (1987) for determining novel species for bacterial strains.

Genome sequencing of strain ASO4wet ${ }^{\mathrm{T}}$ resulted in a single linear chromosome typical for members of the genus Streptomyces consisting of 7,377,472 bp. The $\mathrm{G}+\mathrm{C}$ content was $70.24 \mathrm{~mol} \%$. 6,332 coding sequences, 59 tRNA genes, and six rRNA operons were found after NCBI PGAP annotation. Analysis by using RAST server revealed that only $20 \%$ of the annotated genes were assigned to subsystems (Fig. 6). Among the subsystem categories present in the genome, amino acids and derivatives metabolism had the highest feature counts (360), followed by carbohydrates metabolism which had 347 feature counts. However, only one feature count detected for dormancy and sporulation, which is different from the some other Streptomyces strains that have at least 10 feature counts (Busarakam et al. 2014; Ser et al. 2018; Quinn et al. 2020). The antiSMASH server predicted 23 secondary metabolite biosynthesis gene clusters, with six clusters showed more than $60 \%$ similarities to known biosynthetic gene clusters: hopene biosynthetic gene cluster $(61 \%)$, planosporicin biosynthetic gene cluster $(100 \%)$, geosmin biosynthetic gene cluster $(100 \%)$, isorenieratene biosynthetic gene cluster (62\%), ectoine biosynthetic gene cluster (100\%), and desferrioxamine E biosynthetic gene cluster $(100 \%)$.

Besides the result of genotypic studies such as $16 \mathrm{~S}$ rRNA gene analysis and DNA-DNA hybridisation, strain ASO4wet ${ }^{\mathrm{T}}$ can also be discriminated from its closely related type strains by some phenotypic properties (Table 2). Lipase (C14) activity could not 
Table 2 Phenotypic properties that distinguish strain ASO4wet ${ }^{\mathrm{T}}$ from the most closely related Streptomyces species

\begin{tabular}{|c|c|c|c|c|}
\hline Characteristics & 1 & 2 & 3 & 4 \\
\hline Esterase (C4) & + & $(+)$ & $(+)$ & + \\
\hline Lipase (C14) & - & - & + & - \\
\hline Trypsin & + & + & + & - \\
\hline Chymotripsin & + & + & + & - \\
\hline$\alpha$-galactosidase & - & - & - & - \\
\hline$\beta$-galactosidase & + & - & - & - \\
\hline$\beta$-glucoronidase & - & - & $(+)$ & $(+)$ \\
\hline$\alpha$-glucosidase & + & + & + & + \\
\hline$\beta$-glucosidase & - & $(+)$ & + & + \\
\hline Glucose & + & + & + & + \\
\hline Arabinose & + & - & ++ & + \\
\hline Sucrose & + & + & ++ & ++ \\
\hline Xylose & ++ & ++ & ++ & ++ \\
\hline Inositol & ++ & + & ++ & ++ \\
\hline Mannose & $(+)$ & + & - & + \\
\hline Fructose & $(+)$ & + & - & + \\
\hline Rhamnose & + & + & - & + \\
\hline Raffinose & ++ & + & ++ & ++ \\
\hline Cellulose & - & + & - & - \\
\hline Polar lipids & $\begin{array}{l}\text { DPG, PG, PE, PME, PIM, } \\
\text { PGL, } 3 \text { GLs }\end{array}$ & $\begin{array}{l}\text { DPG, PG, PE, PME, PI, } 3 \text { PLs, } 2 \\
\text { PGLs, } 2 \text { GLs* }\end{array}$ & $\begin{array}{l}\text { DPG, PG, PME, PE, } \\
\text { PIM, PI, 6PLs** }\end{array}$ & $\begin{array}{l}\text { DPG, PG, PME, } \\
\text { PIM, PI, 5PLs** }\end{array}$ \\
\hline $\begin{array}{l}\text { Predominant } \\
\text { Menaquinone }\end{array}$ & MK-9(H8) & MK-9(H8)* & MK-9(H8)** & $\begin{array}{l}\text { MK-9(H4), } \\
\text { MK-9(H6), } \\
\text { MK-9(H8)** }\end{array}$ \\
\hline
\end{tabular}

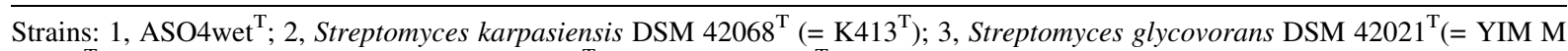
$\left.10366^{\mathrm{T}}\right) ; 4$, Streptomyces abyssalis DSM $42024^{\mathrm{T}}\left(=\right.$ YIM M $\left.10400^{\mathrm{T}}\right)$

++ better growth; + positive result or good growth; - negative result or no growth; $(+)$ weakly positive result or weak growth. DPG, diphosphatidylglycerol; PG, phosphatidylglycerol; PE, phosphatidylethanolamine; PME, phosphatidyl-N-methyl-ethanolamine; PI, phosphatidylinositol; PIM, phosphatidylinositol mannoside; PL, unknown phospholipid; PGL, unknown phosphoglycolipid; GL, unknown glycolipid. *Data from Veyisoglu et al. (2014); ** data from Xu et al. (2012)

be observed for strain ASO4wet ${ }^{\mathrm{T}}$, whereas Streptomyces glycovorans DSM $42021^{\mathrm{T}}$ was positive. There was the $\beta$-galactosidase activity for strain ASO4wet ${ }^{\mathrm{T}}$, while in the all compared type strains, it was not detected. Strain ASO4wet ${ }^{\mathrm{T}}$ had no $\beta$-glucosidase activity, while all of the tested type strains possessed it. Strain ASO4wet ${ }^{\mathrm{T}}$ exhibited good growth on the ISP 9 medium supplemented with arabinose, while Streptomyces karpasiensis DSM $42068^{\mathrm{T}}$ showed no growth. Phosphatidylinositol mannoside was detected in strain ASO4wet ${ }^{\mathrm{T}}$ but not in Streptomyces karpasiensis DSM $42068^{\mathrm{T}}$ based on data previously reported by Veyisoglu et al. (2014).
In conclusion, strain ASO4wet ${ }^{\mathrm{T}}$ represents a novel species in the genus Streptomyces, for which the name Streptomyces bathyalis sp. nov. is proposed.

\section{Description of Streptomyces bathyalis sp.nov.}

Streptomyces bathyalis (ba.thy.al'is. L. neutrum substantive from the Greek bathys (deep) the part of the pelagic zone between 1,000 and 4,000 m).

Aerobic, Gram-positive actinomycete that forms branched substrate mycelium. Aerial hyphae can be seen only in ISP3 and ISP7. Spores are not detected in any medium tested even after 4 weeks of incubation at $30{ }^{\circ} \mathrm{C}$. It grows well on ISP2, ISP3, ISP4, and ISP5 
after 2 weeks incubation at $30{ }^{\circ} \mathrm{C}$. Optimum growth occurs at $25-30{ }^{\circ} \mathrm{C}$ and at $\mathrm{pH} 7$. The $\mathrm{NaCl}$ tolerance is 0-10\% (w/v) NaCl. Positive for esterase (C4), trypsin, chymotrypsin, $\beta$-galactosidase, and $\alpha$-glucosidase. Negative for lipase (C14), $\alpha$-galactosidase, $\beta$-glucuronidase, and $\beta$-glucosidase. Glucose, arabinose, sucrose, xylose, inositol, mannose, fructose, rhamnose, raffinose are used as sole carbon sources, but not cellulose. Major fatty acids are iso-C16:0 $(35.0 \%)$, anteiso-C15:0 (22.0\%), and iso-C15:0 $(13.8 \%)$. The major menaquinone is MK-9(H8). The diagnostic amino acid in the peptidoglycan is LL-diaminopimelic acid. Glucose and xylose are present in whole-cell hydrolysates. The type strain is ASO4wet ${ }^{\mathrm{T}}\left(=\mathrm{DSM} 106605^{\mathrm{T}}=\right.$ NCCB $\left.100657^{\mathrm{T}}\right)$, isolated from a sponge collected from the North Atlantic Ocean at $1092 \mathrm{~m}$ depth. The genomic DNA $\mathrm{G}+\mathrm{C}$ content of the type strain is $70.24 \mathrm{~mol} \%$. The genome size is $7,377,472$ bp with 6,332 coding sequences, 59 tRNA genes, and six rRNA operons. The complete genome and the 16S rRNA sequence of strain ASO4wet ${ }^{T}$ were deposited at NCBI GenBank with accession number CP048882 and MT036271, respectively.

Acknowledgements The authors thank Romy Schade for excellent technical assistance, Stephanie Schulz and Gabriele Pötter for chemotaxonomic analysis, and Aileen Gollasch for recording the HRESIMS data.

Authors' contributions CR and WL carried out the experiments, analysed the data, and drafted manuscript. CR and WL contributed equally to this work. MR performed scanning electron microscopy. PS conducted ribotyping and MALDI-TOF. RLH carried out fatty acid analysis. CS and BB carried out complete genome analysis. PK performed DDH analysis. PJS collected the sponge and supervised the project. JW supervised the project. MR, PS, RLH, CS, BB, PK, PJS, and JW corrected and reviewed the draft.

Funding Open Access funding enabled and organized by Projekt DEAL. This work was supported by German Federal Ministry of Education and Research (BMBF) under the GermanIndonesian anti-infective cooperation (GINAICO) project, a fellowship awarded by the German Academic Exchange Service (German: Deutscher Akademischer Austauschdienst or DAAD), and The President's Initiative and Networking Funds of the Helmholtz Association of German Research Centres (German: Helmholtz Gemeinschaft Deutscher Forschungszentren or HGF) under Contract Number VH-GS202.

Data availability The GenBank accession number for the 16S rRNA gene sequence of strain ASO4wet ${ }^{T}$ is MT036271.
The GenBank accession number for complete genome of strain ASO4wet $^{\mathrm{T}}$ is CP048882.

\section{Compilance with ethical standards}

Conflict of interest The authors declare no conflict of interest.

Ethics approval This article does not contain any studies with human participants and/or animals performed by any of the authors. The formal consent is not required in this study.

Consent to participate Not applicable.

Consent for publication Not applicable.

Open Access This article is licensed under a Creative Commons Attribution 4.0 International License, which permits use, sharing, adaptation, distribution and reproduction in any medium or format, as long as you give appropriate credit to the original author(s) and the source, provide a link to the Creative Commons licence, and indicate if changes were made. The images or other third party material in this article are included in the article's Creative Commons licence, unless indicated otherwise in a credit line to the material. If material is not included in the article's Creative Commons licence and your intended use is not permitted by statutory regulation or exceeds the permitted use, you will need to obtain permission directly from the copyright holder. To view a copy of this licence, visit http://creativecommons.org/licenses/by/4.0/.

\section{References}

Altschul SF, Gish W, Miller W, Myers EW, Lipman DJ (1990) Basic local alignment search tool. J Mol Biol 215:403-410. doi:https://doi.org/10.1016/S0022-2836(05)80360-2

Ayed A, Slama N, Mankai H, Bachkouel S, ElKahoui S, Tabbene O, Limam F (2018) Streptomyces tunisialbus sp. nov., a novel Streptomyces species with antimicrobial activity. Antonie Van Leeuwenhoek 111:1571-1581. doi:https:// doi.org/10.1007/s10482-018-1046-4

Aziz RK et al (2008) The RAST server: rapid annotations using subsystems technology. BMC Genom 9:75. https://doi.org/ 10.1186/1471-2164-9-75

Bauer A, Kirby W, Sherris J, Turck M (1966) Antibiotic susceptibility testing by a standardized single disk method. Am J Clin Pathol 45:493-496

Baym M, Kryazhimskiy S, Lieberman TD, Chung H, Desai MM, Kishony R (2015) Inexpensive multiplexed library preparation for megabase-sized genomes. PLoS One 10:e128036. https://doi.org/10.1371/journal.pone. 0128036

Blin K, Shaw S, Steinke K, Villebro R, Ziemert N, Lee SY, Medema MH, Weber T (2019) antiSMASH 5.0: updates to the secondary metabolite genome mining pipeline. Nucleic Acids ResOxford University Press 47:W81-W87. https:// doi.org/10.1093/nar/gkz310

Bruce J (1996) Automated system rapidly identifies and characterizes microorganisms in food. Food Tech 50:77-81 
Busarakam K, Bull AT, Girard G, Labeda DP, van Wezel GP, Goodfellow M (2014) Streptomyces leeuwenhoekii sp. nov., the producer of chaxalactins and chaxamycins, forms a distinct branch in Streptomyces gene trees. Antonie Van Leeuwenhoek 105:849-861. https://doi.org/10.1007/ s10482-014-0139-y

Charousová I, Javoreková S, Wink J (2015) Isolation and characterization of Streptomyces rishiriensis (VY31) with antibiotic activity against various pathogenic microorganisms. J Microbiol Biotechnol Food Sci 04:23-27. doi:https://doi.org/10.15414/jmbfs.2015.4.special1.23-27

Collins MD, Shah HN (1984) Fatty acid, menaquinone and polar lipid composition of Rothia dentocariosa. Arch Microbiol 137:247-249

Felsenstein J (1981) Evolutionary trees from DNA sequences: a maximum likelihood approach. J Mol Evol 17:368-376. https://doi.org/10.1007/BF01734359

Felsenstein J (1985) Confidence limits on phylogenies: an approach using the bootstrap. Evolution 39:783. https:// doi.org/10.2307/2408678

Goodfellow M, Busarakam K, Idris H, Labeda DP, Nouioui I, Brown R, Kim B-Y, del Carmen Montero-Calasanz M, Andrews BA, Bull AT (2017) Streptomyces asenjonii sp. nov., isolated from hyper-arid Atacama Desert soils and emended description of Streptomyces viridosporus Pridham et al. 1958. Antonie Van Leeuwenhoek 110: 1133-1148. https://doi.org/10.1007/s10482-017-0886-7

Hall TA (1999) BioEdit: a user-friendly biological sequence alignment editor and analysis program for Windows 95/98/ NT. Nucl Acids Symp Ser 41:95-98

Handayani I, Ratnakomala S, Lisdiyanti P, Alanjary M, Wohlleben W, Mast Y (2018) Complete genome sequence of Streptomyces sp. strain BSE7F, a Bali mangrove sediment actinobacterium with antimicrobial activities. Genome Announc 6:1-3

Hohmann C, Schneider K, Bruntner C, Irran E, Nicholson G, Bull AT, Jones AL, Brown R, Stach JEM, Goodfellow M, Beil W, Krämer M, Imhoff JF, Süssmuth RD, Fiedler H (2009) Caboxamycin, a new antibiotic of the benzoxazole family produced by the deep-sea strain Streptomyces sp. NTK 937. J Antibiot (Tokyo) 62:99-104. https://doi.org/ 10.1038/ja.2008.24

Humble MW, King A, Phillips I (1977) API ZYM: a simple rapid system for the detection of bacterial enzymes. J Clin Pathol 30:275-277

Kämpfer P, Huber B, Buczolits S, Thummes K, Grün-Wollny I, Busse HJ (2008) Streptomyces specialis sp. nov. Int J Syst Evol Microbiol 58:2602-2606. https://doi.org/10.1099/ijs. 0.2008/001008-0

Kemung HM, Tan LTH, Khan TM, Chan KG, Pusparajah P, Goh BH, Lee LH (2018) Streptomyces as a prominent resource of future anti-MRSA drugs. Front Microbiol 9:1-26. https://doi.org/10.3389/fmicb.2018.02221

Koboldt DC, Zhang Q, Larson DE, Shen D, McLellan MD, Lin L, Miller CA, Mardis ER, Ding L, Wilson RK (2012) VarScan 2: somatic mutation and copy number alteration discovery in cancer by exome sequencing. Genome Res 22:568-576. https://doi.org/10.1101/gr.129684.111

Kumar S, Stecher G, Li M, Knyaz C, Tamura K (2018) MEGA $\mathrm{X}$ : molecular evolutionary genetics analysis across computing platforms. Mol Biol Evol 35:1547-1549. https://doi.org/10.1093/molbev/msy096

Kutzner H (1981) The family Streptomycetaceae. In: Starr M, Stolp H, Trüper H, Balons A, Schlegel H (eds) The Prokaryotes: a handbook on habitats, isolation and identification of bacteria. Springer Verlag, Berlin, pp 2028-2090

Landwehr W, Kämpfer P, Glaeser SP, Rückert C, Kalinowski J, Blom J, Goesmann A, Mack M, Schumann P, Atasayar E, Hahnke RL, Rohde M, Martin K, Stadler M, Wink J (2018) Taxonomic analyses of members of the Streptomyces cinnabarinus cluster, description of Streptomyces cinnabarigriseus sp. nov. and Streptomyces davaonensis sp. nov. Int J Syst Evol Microbiol 68:382-393. https://doi. org/10.1099/ijsem.0.002519

Landwehr W, Karwehl S, Schupp PJ, Schumann P, Wink J (2016) Biological active rakicidins A, B and E produced by the marine Micromonospora sp. isolate Guam1582. Adv Biotech Micro 1:555558. https://doi.org/10.19080/AIBM. 2016.01.555558

Lechevalier MP, Lechevalier H (1970) Chemical composition as a criterion in the classification of aerobic actinomycetes. Int J Syst Bacteriol 20:435-443

Li H, Durbin R (2009) Fast and accurate short read alignment with Burrows-Wheeler transform 25: 1754-1760. https:// doi.org/10.1093/bioinformatics/btp324

Liu N, Shang F, Xi L, Huang Y (2013) Tetroazolemycins A and $\mathrm{B}$, two new oxazole-thiazole siderophores from deep-sea Streptomyces olivaceus FXJ8.012. Mar Drugs 11:1524-1533. https://doi.org/10.3390/md11051524

Lucas X, Senger C, Erxleben A, Grüning BA, Döring K, Mosch J, Flemming S, Günther S (2013) StreptomeDB: a resource for natural compounds isolated from Streptomyces species. Nucleic Acids Res 41:D1130-D1136. https://doi.org/10. 1093/nar/gks1253

Luo M, Tang G, Ju J, Lu L, Huang H (2015) A new diketopiperazine derivative from a deep sea-derived Streptomyces sp. SCSIO 04496. Nat Prod Res 30:138-143. https:// doi.org/10.1080/14786419.2015.1045509

Luo Y, Xiao J, Wang Y, Xu J, Xie S (2011) Streptomyces indicus sp. nov., an actinomycete isolated from deep-sea sediment. Int J Syst Evol Microbiol 61:2712-2716. https:// doi.org/10.1099/ijs.0.029389-0

Medema MH, Blin K, Cimermancic P, De Jager V, Zakrzewski P, Fischbach MA, Weber T, Takano E, Breitling R (2011) AntiSMASH: rapid identification, annotation and analysis of secondary metabolite biosynthesis gene clusters in bacterial and fungal genome sequences. Nucleic Acids Res 39:339-346. https://doi.org/10.1093/nar/gkr466

Minnikin DE, O'Donnell AG, Goodfellow M, Alderson G, Athalye M, Schaal A, Parlett JH (1984) An integrated procedure for the extraction of bacterial isoprenoid quinones and polar lipids. J Microbiol Methods 2:233-241. https://doi.org/10.1016/0167-7012(84)90018-6

Minnikin DE, Patel PV, Alshamaony L, Goodfellow M (1977) Polar lipid composition in the classification of Nocardia and related bacteria. Int J Syst Bacteriol 27:104-117

Quinn GA, Abdelhameed AM, Alharbi NK, Cobice D, Adu SA, Swain MT, Castro HC, Facey PD, Bakshi HA, Tambuwala MM, Banat IM (2020) The isolation of a novel Streptomyces sp. CJ13 from a traditional Irish folk medicine alkaline grassland soil that inhibits multiresistant 
pathogens and yeasts. Appl Sci 11:173. https://doi.org/10. 3390/app11010173

Quintana ET, Wierzbicka K, Mackiewicz P, Osman A, Fahal AH, Hamid ME, Zakrzewska-Czerwinska J, Maldonado LA, Goodfellow M (2008) Streptomyces sudanensis sp. nov ., a new pathogen isolated from patients with actinomycetoma. Antonie Van Leeuwenhoek 93:305-313. https://doi.org/10.1007/s10482-007-9205-z

Risdian C, Primahana G, Mozef T, Dewi RT, Ratnakomala S, Lisdiyanti P, Wink J (2018) Screening of antimicrobial producing actinobacteria from Enggano Island, Indonesia. AIP Conf Proc 2024: 020039. https://doi.org/10.1063/1. 5064325

Ritacco FV, Haltli B, Janso JE, Greenstein M, Bernan VS (2003) Dereplication of Streptomyces soil isolates and detection of specific biosynthetic genes using an automated ribotyping instrument. J Ind Microbiol Biotechnol 30:472-479. https://doi.org/10.1007/s10295-003-0038-0

Sasser M (1990) Identification of bacteria by gas chromatography of cellular fatty acids. MIDI Inc., Newark

Schumann P, Maier T (2014) MALDI-TOF Mass Spectrometry Applied to Classification and Identification of Bacteria. in Goodfellow, M., Sutcliffe, I., and Chun, J. (eds) Methods in Microbiology. Academic Press: 275-306. https://doi.org/ 10.1016/bs.mim.2014.06.002

Schumann P, Pukall R (2013) The discriminatory power of ribotyping as automatable technique for differentiation of bacteria. Syst Appl MicrobiolElsevier GmbH: 36:369-375. https://doi.org/10.1016/j.syapm.2013.05.003

Ser H, Ab Mutalib N-S, Yin W, Goh B-H, Lee L-H, Chan K (2018) Genome sequence of Streptomyces antioxidans MUSC $164^{\mathrm{T}}$ isolated from mangrove forest. Prog Microbes Mol Biol 1:4-6. https://doi.org/10.36877/pmmb.a0000001

Shirling EB, Gottlieb D (1966) Methods for characterization of Streptomyces species. Int $\mathrm{J}$ Syst Evol Microbiol 16:313-340

Skerman VBD, McGowan V, Sneath PHA (1980) Approved lists of bacterial names. Int J Syst Evol Microbiol 30:225-420. https://doi.org/10.1099/00207713-30-1-225

Staneck JL, Roberts GD (1974) Simplified approach to identification of aerobic actinomycetes by thin-layer chromatography. Appl Microbiol 28:226-231

Tamura K, Nei M (1993) Estimation of the number of nucleotide substitutions in the control region of mitochondrial DNA in humans and chimpanzees. Mol Biol Evol 10:512-526. https://doi.org/10.1093/oxfordjournals.molbev.a040023

Tatusova T, DiCuccio M, Badretdin A, Chetvernin V, Nawrocki EP, Zaslavsky L, Lomsadze A, Pruitt KD, Borodovsky M, Ostell J (2016) NCBI prokaryotic genome annotation pipeline. Nucleic Acids Res 44:6614-6624. https://doi.org/ 10.1093/nar/gkw569

Thompson JD, Higgins DG, Gibson TJ (1994) CLUSTAL W: improving the sensitivity of progressive multiple sequence alignment through sequence weighting, position-specific gap penalties and weight matrix choice. Nucleic Acids Res 22:4673-4680. https://doi.org/10.1093/nar/22.22.4673

Tian X, Long L, Wang F, Xu Y, Li J, Zhang J, Zhang C, Zhang S, Li W (2012) Streptomyces nanhaiensis sp. nov ., a marine streptomycete isolated from a deep-sea sediment. Int J Syst Evol Microbiol 62:864-868. https://doi.org/10. 1099/ijs.0.031591-0

Tortorella E, Tedesco P, Esposito FP, January GG, Fani R, Jaspars M, De Pascale D (2018) Antibiotics from deep-sea microorganisms: current discoveries and perspectives. Mar Drugs 16:1-16. https://doi.org/10.3390/md16100355

Veyisoglu A, Tatar D, Cetin D, Guven K, Sahin N (2014) Streptomyces karpasiensis sp. nov., isolated from soil. Int J Syst Evol Microbiol 64:827-832. https://doi.org/10.1099/ ijs.0.056275-0

Wayne LG, Brenner DJ, Colwell RR, Grimont PAD, Kander O, Krichevsky MI, Moore LH, Moore WEC, Murray RGE, Stackebrandt E, Starr MP, Truper HG (1987) Report of the ad hoc committee on reconciliation of approaches to bacterial systematics. Int J Syst Bacteriol 37:463-464. https:// doi.org/10.1099/00207713-37-4-463

Williams ST, Goodfellow M, Alderson G, Wellington EMH, Sneath PHA, Sackin MJ (1983) Numerical classification of Streptomyces and related genera. J Gen Microbiol 129:1743-1813. https://doi.org/10.1099/00221287-129-61743

Wink J, Schumann P, Atasayar E, Klenk HP, Zaburannyi N, Westermann M, Martin K, Glaeser SP, Kämpfer P (2017) 'Streptomyces caelicus', an antibiotic-producing species of the genus Streptomyces, and Streptomyces canchipurensis $\mathrm{Li}$ et al. 2015 are later heterotypic synonyms of Streptomyces muensis Ningthoujam et al. 2014. Int J Syst Evol Microbiol 67: 548-556. https://doi.org/10.1099/ijsem.0. 001612

Xiao J, Wang Y, Luo Y, Xie SJ, Ruan JS, Xu J (2009) Streptomyces avicenniae sp. nov., a novel actinomycete isolated from the rhizosphere of the mangrove plant Avicennia mariana. Int J Syst Evol Microbiol 59:2624-2628. https:// doi.org/10.1099/ijs.0.009357-0

Xu Y, He J, Tian XP, Li J, Yang LL, Xie Q, Tang SK, Chen YG, Zhang S, Li WJ (2012) Streptomyces glycovorans sp. nov., Streptomyces xishensis sp. nov. and Streptomyces abyssalis sp. nov., isolated from marine sediments. Int J Syst Evol Microbiol 62: 2371-2377. https://doi.org/10.1099/ijs.0. 035386-0

Ziemke F, Hofle MG, Lalucat J, Rossello-Mora R (1998) Reclassification of Shewanella putrefaciens Owen's genomic group II as Shewanella baltica sp. nov. Int J Syst Bacteriol 48:179-186

Publisher's note Springer Nature remains neutral with regard to jurisdictional claims in published maps and institutional affiliations. 